\title{
PEMANFAATAN PERTANIAN RUMAH TANGGA (PEKARANGAN RUMAH) DENGAN TEKNIK BUDIDAYA TANAMAN SAYURAN SECARA VERTIKULTUR
}

\author{
Dyah Pikanthi Diwanti \\ Fakultas Agama Islam, Universitas Muhammadiyah Yogyakarta \\ dyahpikanthidiwanti@gmail.com
}

DOI : 10.31604/j.martabe.v1i3.101-107

\begin{abstract}
This empowerment program to capitalize on the grounds of the House belonging to citizens to land with the function optimization technique of vegetable cultivation in vertikultur. Types of plants particularly Horticulture Vegetables still process it has rarely done by local communities, to meet the needs of vegetables by the community is filled with how to buy vegetable needs. In addition to the problems regarding the inability of the community to meet the needs of the vegetable, the potential home or yard of land around the House is underutilized by society. From some of these problems have to do activities that can deal with the problems of land use in agricultural techniques using empty vertikultur. For that is the necessary preliminary understanding of the importance of farming households are becoming potential citizens Sadang in land use lawns. The method of implementation is carried out with the guidance, training and mentoring to the citizens and farmers groups to maximize the yield of empowerment, also, a leaflet as a means of education is given as a guide. As for the measures being undertaken: the first Socialization by expert Vertikultur to the citizens and farmers groups, both starting from the third nursery Training Mentoring related to utilization of agricultural household (Yard House) with engineering cultivation of vegetables in vertikultur. Of the implementation of the activities of the utilization of the grounds of the House, there is some indication of the success of the program. In between the attitudes of citizens showed positive changes, namely an increase in the awareness of the citizens who are the majority of farmers of the importance of the utilization of yard for a vegetable crop cultivation in vertikultur with join engagement activities, the enthusiasm of the citizens/farmers and awareness for land use lawns as well as the existence of the pilot project by utilizing the vegetable cultivation land yard in vertikultur can be carried out.
\end{abstract}

Keywords: Yard House, Cultivation Techniques, Vertikultur.

\begin{abstract}
Abstrak
Program pemberdayaan ini untuk memanfaatkan pekarangan rumah milik warga dalam rangka pengoptimalan fungsi lahan dengan teknik budidaya tanaman sayuran secara vertikultur. Jenis tanaman holtikultura khususnya sayuran masih jarang dilakukan proses budidayanya oleh masyarakat sekitar, sehingga untuk memenuhi kebutuhan sayuran oleh masyarakat dipenuhi dengan cara membeli kebutuhan sayuran. Selain permasalahan mengenai ketidakmampuan masyarakat dalam memenuhi kebutuhan sayuran, potensi pekarangan rumah atau lahan di sekitar rumah kurang dimanfaatkan
\end{abstract}


oleh masyarakat. Dari beberapa permasalahan tersebut perlu dilakukan kegiatan yang dapat menangani permasalahan dengan pemanfaatan lahan kosong menggunakan teknik pertanian secara vertikultur. Untuk itulah diperlukan pemahaman awal tentang pentingnya pertanian rumah tangga yang menjadi potensi warga Sadang dalam pemanfaatan lahan pekarangan. Metode pelaksanaan dilakukan dengan penyuluhan, pelatihan dan pendampingan kepada Warga dan kelompok tani untuk memaksimalkan hasil pemberdayaan selain itu leaflet sebagai sarana edukasi diberikan sebagai panduan. Adapun langkah-langkah yang dilakukan: pertama Sosialisasi oleh pakar Vertikultur kepada warga dan kelompok tani, kedua Pelatihan mulai dari pembibitan ketiga Pendampingan terkait dengan pemanfaatan pertanian rumah tangga (Pekarangan Rumah) dengan teknik budidaya tanaman sayuran secara vertikultur. Dari rangkaian pelaksanaan kegiatan pemanfaatan pekarangan rumah, ada beberapa indikasi keberhasilan dari program tersebut. Di antaranya sikap warga yang menunjukan perubahan positif yaitu adanya peningkatan kesadaran warga yang mayoritas petani akan pentingnya pemanfaatan pekarangan untuk penanaman tanaman sayuran secara vertikultur dengan ikut keterlibatan kegiatan, antusiasme warga/ petani dan kesadaran untuk pemanfaatan lahan pekarangan serta adanya pilot project budidaya tanaman sayur dengan memanfaatkan lahan pekarangan secara vertikultur dapat terlaksana.

Kata kunci: Pekarangan Rumah, Teknik Budidaya Tanaman, Vertikultur.

\section{PENDAHULUAN}

Pemberdayaan masyarakat
merupakan program yang sangat
bermanfaat bagi masyarakat. Salah
satunya dapat dilaksanakan dalam
bentuk Kuliah Kerja Nyata (KKN).
Dalam KKN ini dosen dan mahasiswa
saling interaksi dengan masyarakat dan
lingkungan sekitarnya. Dalam KKN ini
pembangunan masyarakat semakin kuat
oleh adanya agen perubahan (agent of
change). Agent of change melakukan
perubahan inovasi yang terencana yaitu
dengan pemberdayaan masyarakat.
Pemberdayaan masyarakat adalah
proses, cara ataupun perbuatan
membuat berdaya yakni kemampuan
bertindak yang berupa upaya. Konteks
pemberdayaan masyarakat ini sangat
sesuai diterapkan dalam situasi dimana
masyarakat memerlukan pendampingan
untuk memberdayakan dirinya sendiri.
Kondisi ini menjadi salah satu
pertimbangan dilaksanakannya KKN di
dusun Sadang.

Dusun Sadang merupakan salah satu dusun yang termasuk ke dalam Kecamatan Nanggulan, Kabupaten Kulon Progo Daerah Istimewa Yogyakarta. Desa Sadang pada bagian utara berbatasan dengan Dusun Tanjunggunung dan pada bagian Barat berbatasan dengan Desa GiriPurwo. Pada bagian selatan Dusun Sadang berbatasan dengan Dusun Banyuroto dan pada bagian Timur berbatasan dengan Dusun Kemukus. Desa Sadang memiliki luas wilayah $50 \mathrm{Ha}$. Luas wilayah ini digunakan sebagai lahan pertanian dan lahan pemukiman warga. Pertanahan yang berada di Dusun Sadang di miliki oleh Dusun, perorangan dan Pemerintah.

Dusun Sadang berjarak $1 \mathrm{Km}^{2}$ dari kecamatan Nanggulan, untuk jarak dengan Kabupaten Kulonprogo berjarak $8,6 \mathrm{Km}^{2}$ dan berjarak $24 \mathrm{Km}^{2}$ dari provinsi kota Daerah Istimewa Yogyakarta. Lebih dari $80 \%$ penduduk Desa Sadang sendiri bermata pencaharian sebagai petani padi dengan 
luas kepemilikan lahan di Desa Sadang sendiri mencapai 15 Ha dengan kondisi lahan pertanian mayoritas petani sawah yang telah menggunakan irigasi teknis. Dilihat dari aspek demografis dan ketenagakerjaan, Desa Sadang memiliki penduduk berjumlah 664 jiwa. Berdasarkan kelompok usia/umur, Desa Sadang memiliki 307 jiwa yang berkelamin laki-laki dan 357 jiwa untuk yang berkelamin perempuan. Berdasarkan kelompok agama sebanyak 664 jiwa merupakan penduduk beragama Islam. Untuk jumlah penduduk menurut tingkat pendidikannya, sebanyak 7 jiwa tidak menempuh pendidikan sekolah, 27 jiwa telah menempuh pendidikan Sekolah Dasar, 38 jiwa menempuh pendidikan SMP (Supangkat dkk, 2013).

Adapun masalah yang dihadapi penduduk Dusun Sadang adalah bahwa jenis tanaman holtikultura khususnya sayuran masih jarang dilakukan proses budidayanya oleh masyarakat sekitar, sehingga untuk memenuhi kebutuhan sayuran oleh masyarakat dipenuhi dengan cara membeli kebutuhan sayuran. Selain permasalahan mengenai ketidakmampuan masyarakat dalam memenuhi kebutuhan sayuran, potensi pekarangan rumah atau lahan di sekitar rumah kurang dimanfaatkan oleh masyarakat. Kegiatan yang dijalankan selama satu bulan di Dusun Sadang, Kecamatan Nanggulan, Kabupaten Kulon Progo, Daerah Istimewa Yogyakarta yang dilaksanakan KKN UMY sangat dirasakan oleh warga Dusun Sadang.

Solusi dari permasalahan yang ada di masyarakat Dusun Sadang adalah dengan peningkatan kapasitas dan pendampingan dalam pemanfaatan lahan melalui budidaya tanaman sayur secara Vertikultur. Pengertian vertikultur secara umum bisa diartikan sebagai teknik bercocok tanam secara vertikal dengan menyusun tanaman secara bertingkat dari bawah keatas. Teknik vertikultur bisa dilakukan menggunakan berbagai macam wadah (tempat media tanam) seperti pipa paralon, botol bekas, pot, polybag atau wadah lainnya tergantung kreatifitas. Pada dasarnya teknik bercocok tanam vertikultur tidak jauh berbeda dengan bercocok tanam konvensional, hanya cara meletakkan/menyusun tanamannya saja yang berbeda (Liferdi dkk, 2016). Pertanian rumah tangga saat ini sedang banyak dilakukan, namun persepsi masyarakat terkait ilmu, tempat dan waktu menjadikan kendala untuk membuat pertanian rumah tangga padahal praktik ini merupakan salah satu wujud pengentasan kemiskinan dalam hal pengurangan pengeluaran rumah tangga terhadap pangan. Seorang ibu biasanya sibuk mengurus keperluan rumah tanggannya, seorang ayah biasanya sibuk bekerja, sedangkan seorang anak biasanya sibuk bermain atau belajar.

Berangkat dari pemikiran ini, KKN memasukkan program pemanfaatan lahan pekarangan dengan sasaran ibu - ibu. Hal tersebut dilakukan karena ibu - ibu pedukuhan Sadang kesusahan jika ingin berbelanja keperluan memasak karena jarak antara pasar sangat jauh. Dengan begitu, dampaknya bisa lebih besar apabila program ini ditujukan ke ibu - ibu.

Adapun Sistem pertanian Vertikultur adalah sistem budidaya pertanian yang dilakukan secara vertikal tau bertingkat. Teknik yang digunakan sangat sederhana namun butuh ketelatenan dalam pemeliharaan. Ada beberapa tipe Vertikultur yakni dengan media botol, paralon dan bambu. Beberapa jenis sayuran yang dapat ditanam dalam budidaya ini yaitu Selada , sawi, seledri, bayam dan kangkung (Widarto, 2016). Adapun 
media tanamnya yakni campuran antara tanah, pasir dan pupuk kandang atau kompos dengan perbandingan yang sama. Budidaya ini memiliki banyak keuntunngan: pertama Efisiensi dalam penggunaan lahan, kedua mudah dalam pemeliharaan, ketiga Penghematan penggunaan pupuk, keempat Praktis dan mudah dalam kontrol pertumbuhan rumput atau gulma, kelima dapat dipindahkan dengan mudah, keenam tanaman sayuran yang dipanen lebih sehat dan segar, ketujuh hemat air dan menambah estetika.

\section{METODE PELAKSANAAN}

Metode pelaksanaan dilakukan dengan penyuluhan, pelatihan dan pendampingan kepada Warga dan kelompok tani untuk memaksimalkan hasil pemberdayaan.

Adapun langkah pertama, Jasa penyuluhan pertanian rumah tangga dengan teknik Vertikultur bagi warga petani/ kelompok tani diikuti oleh $75 \%$ anggota. Kegiatan ini dilakukan dengan mengumpulkan warga semua anggota Kelompok Tani.

Kedua, Jasa pelatihan pertanian rumah tangga diikuti oleh $75 \%$ anggota. Pelatihan dengan langsung praktek cara penanaman dan perawatan tanaman melalui polibag/ media sederhana dengan teknik vertikultur.

Ketiga, Jasa pendampingan pengelolaan pertanian Rumah tangga ada warga petani diikuti oleh warga dan kelompok tani. Dilakukan pendampingan dalam pengelolaan dengan teknik vertikultur.

Pendampingan dan monev Kegiatan ini dilakukan secara periodik untuk membina dan mendampingi mitra. Leaflet pemanfaatan Pemanfaatan Pertanian Rumah Tangga (Pekarangan
Rumah) Dengan Teknik Budidaya Tanaman Sayuran Secara Vertikultur.

\section{HASIL DAN PEMBAHASAN}

Adapun langkah-langkah yang dilakukan: 1) Sosialisasi, Sosialisasi dilaksanakan untuk menambah wawasan dan ilmu masyarakat setempat bahwa terdapat potensi yang dapat dikembangkan, baik dari segi SDA maupun SDM-nya. Sosialisasi juga dilaksanakan untuk mengatasi permasalahan yang ada di Dusun Sadang diantaranya kurangnya minat masyarakat memanfaatkan pekarangan rumah. Sosialisasi berupa sosialisasi pembuatan vertikultur untuk budidaya tanaman sayuran target sasaran ibu-ibu Dusun Sadang.

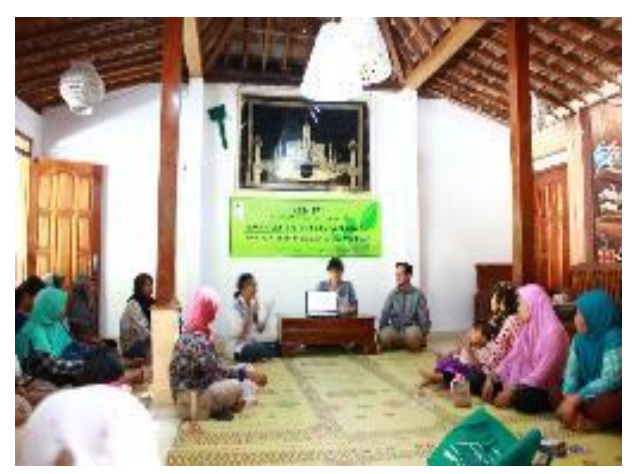

$\begin{aligned} \text { Gambar 1: } & \text { Sosialisasi/ Penyuluhan } \\ & \text { Vertikultur pada Warga } \\ & \text { dan kelompok Tani }\end{aligned}$

Langkah 2) Pelatihan. Pelatihan dilaksanakan untuk program pokok (Pemberdayaan masyarakat) dimana dengan praktik langsung untuk mencapai tujuan yang bersifat psikomotorik. Pelatihan mendatangkan narasumber dari pihak luar (pemateri) dan dari mahasiswa pelaksana KKN 171 dari fakultas pertanian. Pelatihan yang akan dilaksanakan yaitu, Pembuatan vertikultur untuk budidaya tanaman sayuran dengan target sasaran 
ibu-ibu yang dilakukan dengan pemateri dari mahasiswa peserta KKN 171 dari fakultas pertanian.

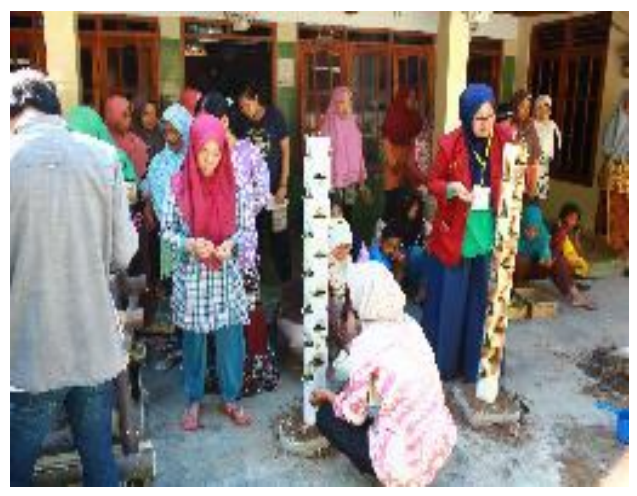

Gambar 2: Pelatihan Vertikultur

Langkah 3) Pendampingan, dilakukan pendampingan dalam pengelolaan tanaman sayuran yang ada dipolibag untuk selanjutnya bisa dilakukan secara mandiri.

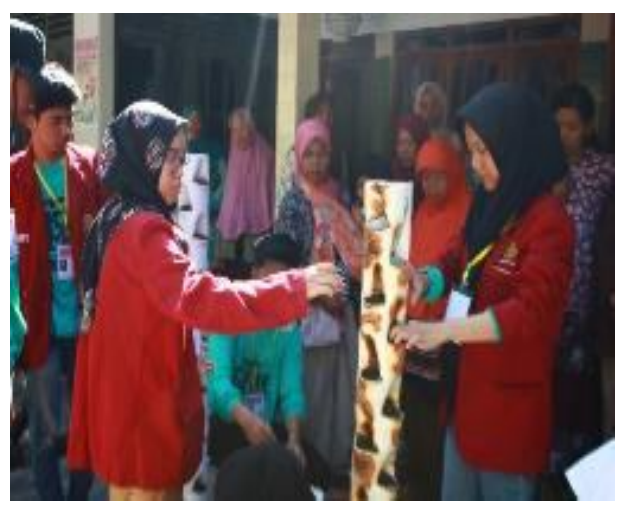

Gambar 3: Pendampingan Vertikultur

Langkah 4) Pembuatan Leaflet Cara Pemanfaatan Pertanian Rumah Tangga (Pekarangan Rumah) Dengan Teknik Budidaya Tanaman Sayuran Secara Vertikultur. Untuk mempermudah pemanfaatan pertanian rumah tangga dibuat maka diperlukan panduan. Panduan berupa leaflet dibagikan kepada warga khususnya kelompok tani yang senantiasa belajar.
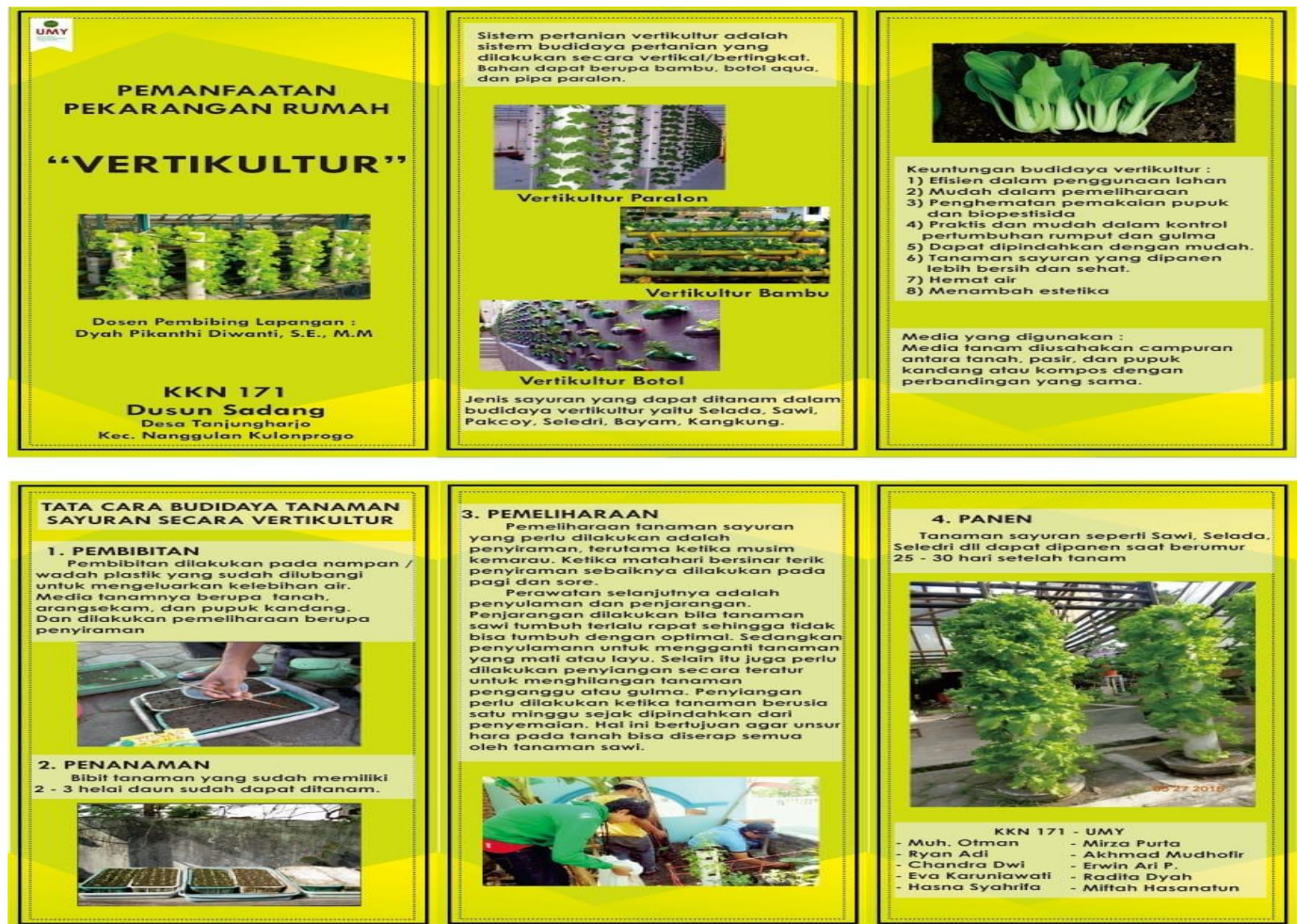

Gambar 4. Panduan Leaflet Teknik Budidaya Tanaman Sayuran Secara Vertikultur 
Adapun hasil pelaksanaan:

1) Pembibitan, dilakukan pada nampan / wadah plastik yang sudah dilubangi untuk mengeluarkan kelebihan air. Media tanamnya berupa tanah, arangsekam dan pupuk kandang dan dilakukan penyiraman sebagai bentuk pemeliharaan.
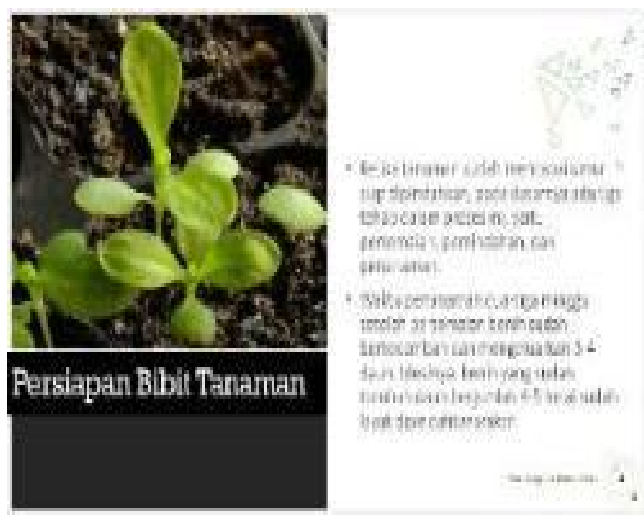

Gambar 5: Pembibitan

2) Penanaman, Penanaman bibit dilakukan pada tanaman yang sudah memiliki 2-3 helai daun.

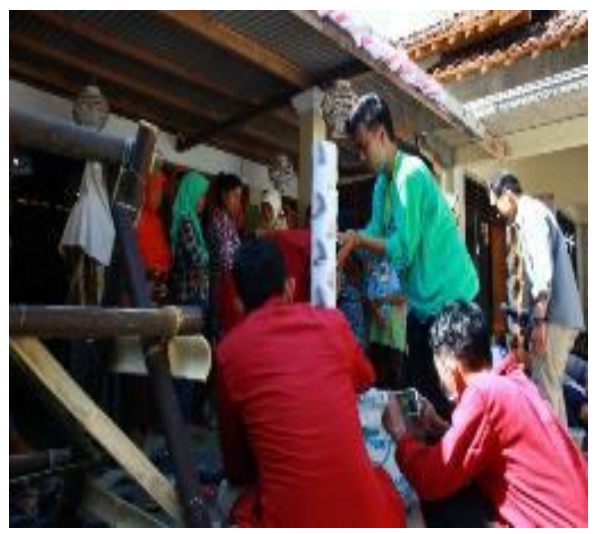

Gambar 6: Penanaman

3). Pemeliharaan, Pemeliharaan tanaman sayuran yang perlu dilakukan yakni dengan penyiraman, terutama di musim kemarau, perawatan selanjutnya adalah penyulaman dan penjarangan. Dilakukan bila tanaman sawi tumbuh terlalu rapat sehingga mengalami kesulitan untuk tumbuh secara optimal. Penyuaman dilakukan untuk mengganti yang mati atau layu. Selain itu dilakukan penyiangan secara teratur untuk menghilangkan tanaman dari pengganggu/ gulma. Biasanya dilakukan ketika tanaman berusia satu minggu sejak penyemaian.

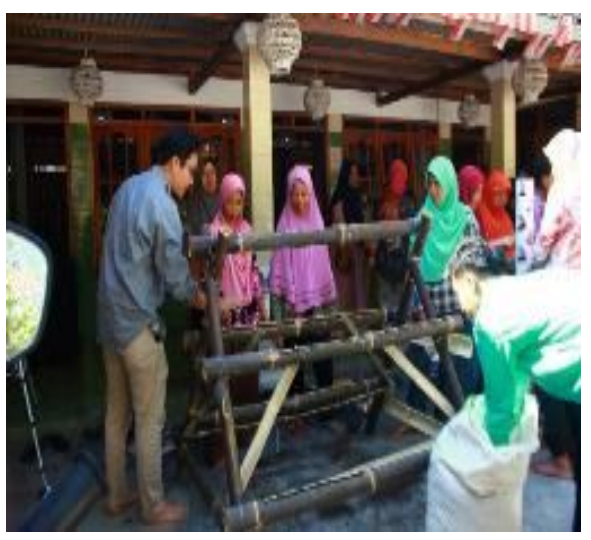

Gambar 7: Pemeliharaan

\section{Capaian Pelaksanaan Program Pemanfaatan Pertanian Rumah Tangga (Pekarangan Rumah)Dengan Teknik Budidaya Tanaman Sayuran Secara Vertikultur}

Capaian kegiatan ini terindikasi dari pertama perubahan mindset warga akan pemanfaatan pekarangan rumah dengan teknik budidaya tanaman sayuran secara Vertikultur ini dapat dilihat dari antusias warga dalam mengikuti kegiatan pelatihan dan pendampingan kegiatan. Kedua.Pemanfaatan lahan yang tidak produktif menjadi lahan produktif dimana terlihat dari keterlibatan $25 \mathrm{kk}$ warga dusun Sadang yang mampu melakukan kegiatan di pekarangan rumah mereka dan memanfaatkan lahan kosong untuk budidaya. Hasil Panen, Tanaman sayuran seperti Sawi, Selada. Seledri dipanen saat berumur 25-30 hari setelah ditanam. 


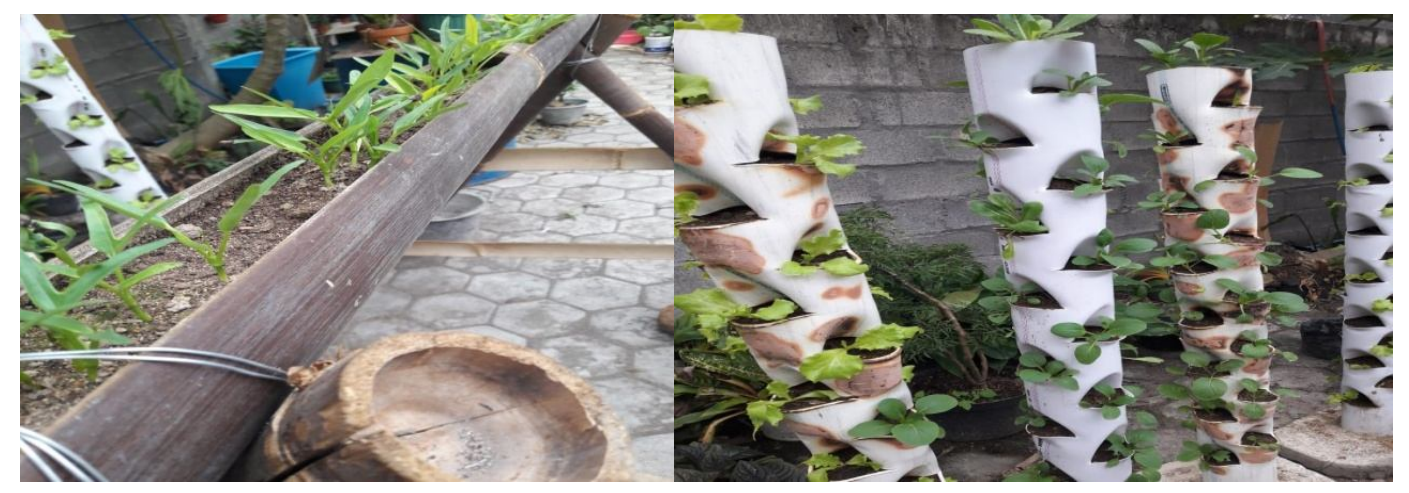

(Gambar 7.Panen)

\section{SIMPULAN}

Dari rangkaian
kegiatan pelaksanaan
pekarangan rumah, ada beberapa indikasi keberhasilan dari program tersebut. Di antaranya sikap warga yang menunjukan perubahan positif yaitu adanya peningkatan kesadaran warga yang mayoritas petani akan pentingnya pemanfaatan pekarangan untuk penanaman tanaman sayuran secara vertikultur, antusiasme warga/ petani dan kesadaran untuk pemanfaatan lahan pekarangan. Selain itu menghasilkan suatu produk panen tanaman yang dilengkapi dengan leaflet sebagai sarana edukasi tentang bagaimana proses Vertikultur.

Berdasarkan program ini menunjukan bahwa kebutuhan pangan sebenarnya bisa dipenuhi dari pemanfaatan pekarangan rumah untuk peningkatan kesejahteraan masyarakat dan adanya efisiensi kebutuhan rumah tangga.

\section{UCAPAN TERIMA KASIH}

Pengabdi mengucapkan banyak terima kasih : Lembaga Pendidikan, Penelitian dan Pengabdian pada Masyarakat (LP3M) UMY atas penyelenggaraan KKN-PPM 2018. Pemerintah Kabupaten Kulonprogo beserta aparat dari Kelurahan sampai RT dan RW Dusun Klajuran. Mitra Kelompok Tani dan Masyarakat Dusun Klajuran

\section{DAFTAR PUSTAKA}

Diwanti, Dyah Pikanthi. (2018). Pengembangan Potensi Masyarakat melalui pemberdayaan pertanian organik. Jurnal Berdikari 6(1).

Widarto. L. (2016). Vertikultur Bercocok Tanam Secara Bertingkat. Jakarta: Penebar Swadaya.

Liferdi, L dan Cahyo Saparinto. (2016). Vertikultur Tanaman Sayur. Jakarta: Penebar Swadaya.

Supangkat, G. dan Moch N. (2013). Pengembangan Sistem Pertanian Terpadu berbasis Masyarakat di Kecamatan Kalibawang, Kabupaten Kulonprogo, Jurnal Berdikari, UMY. 